\title{
Gender differences in lung cancer: Have we really come a long way, baby?
}

\author{
Jemi Olak, MDa \\ Yolanda Colson, $\mathrm{MD}^{\mathrm{b}}$
}

From Lutheran General Hospital, Park Ridge, Ill, ${ }^{\mathrm{a}}$ and the Division of Thoracic Surgery, Brigham and Women's Hospital, Boston, Mass. $^{\text {b }}$

Received for publication May 18, 2004; accepted for publication May 24, 2004.

Address for reprints: Jemi Olak, MD, Lutheran General Hospital, 1875 Dempster St, Suite 145, Park Ridge, IL 60068 (E-mail: olakmd@aol.com).

J Thorac Cardiovasc Surg 2004;128:346-51 $0022-5223 / \$ 30.00$

Copyright (C) 2004 by The American Association for Thoracic Surgery

doi:10.1016/j.jtcvs.2004.05.025

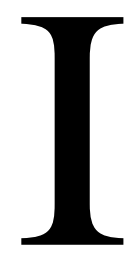

t has been estimated that 173,770 new lung cancers will be diagnosed in the USA in 2004 , and $80,600(46.3 \%)$ will be diagnosed in women. It has also been estimated that 68,510 women will die of lung cancer in 2004, which represents a $4.2 \%$ increase from 2001, when lung cancer took the lives of 65,606 women. Lung cancer currently accounts for $12.7 \%$ of all cancers diagnosed in the United States and for $28.5 \%$ of all cancer deaths. ${ }^{1}$ In 1987 , lung cancer surpassed breast cancer to become the leading cause of cancer death among women. In fact, lung cancer now kills more women annually than breast, uterine, and ovarian cancers combined. Unfortunately, women have come a long way, but not along a good path. Between 1950 and 1994, female lung cancer mortality increased $500 \%$, from $3 \%$ to $22 \% .^{2}$ In 1965 , approximately 30,000 US women died of 10 categories of tobacco-related illnesses, but by 1985 that figure had risen to $106,000 .{ }^{3}$ That tobacco-related diseases including lung cancer are an increasingly major health problem for women is undeniable.

\section{Smoking Patterns in Women and Men}

The lung cancer epidemic began later among women than among men, in large part because of differences in cigarette smoking patterns. Smoking prevalence among women was $18.1 \%$ in 1935 , peaked at $33.3 \%$ in 1965 , and stayed at that level through the late 1970s. Since that time, the rate has declined slowly to its current level of $23.5 \%{ }^{4}$ Unfortunately, women are beginning to smoke at a younger age, owing in large part to successful tobacco advertising campaigns directed toward both adolescents and women. The smoking rate among female high school students, for example, increased from $17.9 \%$ in 1991 to $23.5 \%$ in 1997 and had climbed to $27.7 \%$ by $2001 .{ }^{5}$ Because of the latency between exposure to tobacco and tobacco smoke carcinogens and the development of lung cancer, the ill effects of tobacco will be with us for many decades.

Lung cancer incidence among men is declining at a faster rate than among women, chiefly because of the decrease in smoking prevalence among men. In the last decade, the incidence of lung cancer among men declined by $2.2 \%$ from the previous decade, whereas the incidence of lung cancer among women increased by $0.5 \%$ during the same time period. Table 1 illustrates the trends in lung cancer incidence during the last 3 decades.

\section{Lung Cancer Susceptibility}

More than $85 \%$ of all patients with lung cancer have a cigarette smoking history, yet only $20 \%$ of smokers acquire lung cancer. This suggests that factors other than smoking predispose an individual toward development of lung cancer. Factors that have been implicated include sex, genetic alterations, second-hand smoke, occupational exposure (eg, asbestos), diet, chronic obstructive pulmonary disease, and previous tobacco-associated cancer. Lung cancer incidence among women exceeds that expected from smoking prevalence alone, which raises the question of women's increased susceptibility to this disease. ${ }^{6}$ Several studies have suggested that women may be more susceptible than men to the ill effects of the carcinogens in tobacco and tobacco smoke. ${ }^{6-11}$ Women with lung cancer have been consistently shown to (1) have smoked less on average ( 31 vs 52 pack-years), (2) be younger, (3) be 2 to 3 
times more likely to have never smoked, and (4) get adenocarcinoma more often than their male counterparts. Women were also found to have started smoking at a later age, to smoke brands with lower tar content, and to inhale less deeply than men in a study by Zang and Wynder. ${ }^{8}$ Despite these findings, women had 1.2- to 1.7-fold higher odds of getting lung cancer than men at every level of exposure to cigarette smoke in that study. Although this finding has been confirmed by others, ${ }^{9}$ it has not been corroborated by all studies. ${ }^{12,13}$

\section{Biologic Differences}

Reasons offered to help explain these findings include (1) differences in nicotine metabolism, (2) differences in the cytochrome P-450 enzyme system that activates and detoxifies tobacco and tobacco smoke carcinogens, (3) differences in DNA adduct levels and an individual's ability to repair damaged DNA, and (4) hormonal effects. It has been suggested that women have reduced plasma clearance of nicotine and its metabolites and that these products may be the precursors of tobacco-specific carcinogens. ${ }^{14,15}$ It has also been hypothesized that an individual's ability to activate and detoxify tobacco and tobacco smoke carcinogens and to repair damaged DNA modulates his or her risk of lung cancer. ${ }^{16}$ The schema in Figure 1, adapted from Hecht, ${ }^{17}$ has been proposed to help explain the reasons for differences in lung cancer susceptibility.

Polycyclic aromatic hydrocarbons and nitrosamines are both present in tobacco smoke and exert their effects through both gene mutations and the formation of DNA adducts in target tissues such as the lung. ${ }^{18,19}$ It has been shown that women with lung cancer have gene polymorphisms in the cytochrome P-450 enzymes (CYPlAl, CYP1A2, and CYP3A4) that result in an increased level of DNA adducts and thus a decreased ability to detoxify tobacco carcinogens. ${ }^{20}$ High levels of DNA adducts are believed to play a role in the initiation of carcinogenesis. ${ }^{21}$ Women with the CYP1A1 mutation had a higher lung cancer risk than men (odds ratio 4.98 vs 1.37 ). Women with both CYP1A1 and GSTM1 mutations had a higher lung cancer risk than men (odds ratio 6.54 vs 2.36). Furthermore, women with lung cancer had higher incidences of both CYPIAl and GSTM1 mutations than did women without lung cancer. ${ }^{22,23}$

It has been found that DNA adduct levels are higher among women with lung cancer than among their male counterparts after adjustment for smoking dose. This suggests that women are exposed to higher levels of tobacco carcinogens than men and may thus have a higher relative risk than men of tobacco-induced lung cancer. ${ }^{20,22-23} \mathrm{~A}$ reduced capacity to repair damaged DNA has also been associated with an increased risk of lung cancer, and women
TABLE 1. Trends in lung cancer incidence, United States

\begin{tabular}{ccc}
\hline Decade & Men & Women \\
\hline $1973-1980$ & $+2.2 \%$ & $+6.3 \%$ \\
$1981-1990$ & $-0.2 \%$ & $+3.4 \%$ \\
$1991-1999$ & $-2.2 \%$ & $+0.5 \%$ \\
\hline
\end{tabular}

have been found to have a lower capacity than men for DNA repair. ${ }^{22}$

\section{Hormonal Differences}

The role of hormones, estrogen in particular, as a risk factor for the development of lung cancer is another area of vigorous investigation. Estrogen is known to be a risk factor for the development of adenocarcinoma of the breast, ovary, and endometrium, and lung adenocarcinoma is known to be more common among women than men. Non-small cell lung cancer lines (both squamous cell and adenocarcinoma) have been found to express estrogen receptors. ${ }^{24,25}$ Estrogen may be involved in lung carcinogenesis by activating cell proliferation through an indirect action on lung fibroblasts or by metabolic activation to intermediates that produce DNA adducts and cause oxidative damage. ${ }^{24}$

Further observations that support a role for estrogen in the development of lung adenocarcinoma include the following: (1) Early age ( $<40$ years) at menopause is associated with a decreased risk of lung adenocarcinoma (odds ratio 0.3). (2) Estrogen replacement therapy is associated with an increased risk of lung adenocarcinoma (odds ratio 1.7); however, in that study no adjustment was made for the amount of smoking. (3) A positive interaction of estrogen, smoking, and lung adenocarcinoma has been found (odds ratio 32.4). ${ }^{26}$ In addition, Zang and $\mathrm{Wynder}^{8}$ found that women older than 55 years with lung cancer (particularly adenocarcinoma) were nearly twice as likely as younger women with lung cancer to have never smoked. No similar age-related difference was found among men with lung cancer or among female control subjects.

\section{Genetic Differences}

There is a higher frequency of p53 tumor suppressor gene mutations among women with non-small cell lung cancer than among men with non-small cell lung cancer. There is also a higher DNA adduct level in normal lung tissue in women with lung cancer, which supports the contention that p53 mutations might be responsible in part for higher DNA adduct levels. ${ }^{27}$ It has been found that the frequency of nucleotide transversions at the p53 locus is higher among female smokers with lung cancer than among either male smokers with lung cancer or female never-smokers with lung cancer. ${ }^{28,29}$

$\mathrm{K}$-ras gene mutations have also been found more commonly in female patients with lung cancer $(26.2 \%)$ who 


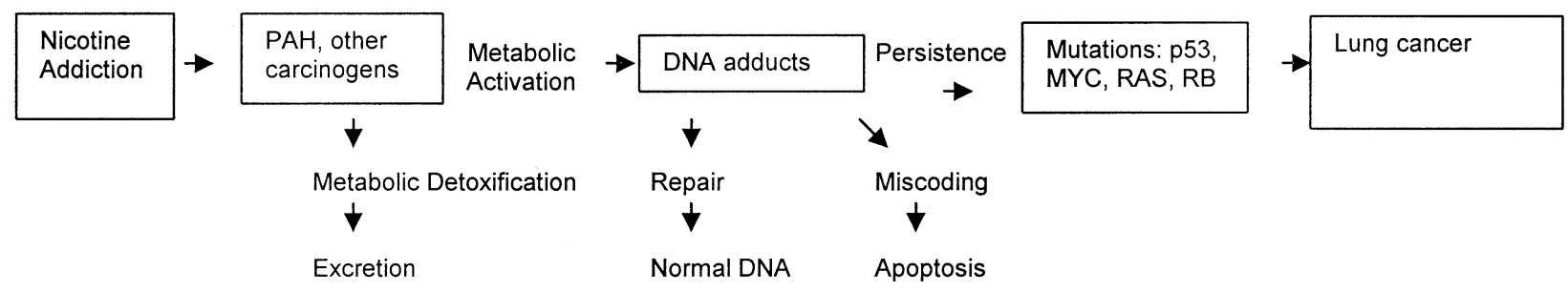

Figure 1. Schema depicting individual differences in response to carcinogens. $P A H$, Polycyclic aromatic hydrocarbons. (Adapted from Hecht SS. Tobacco smoke carcinogens and lung cancer. J Natl Cancer Inst. 1999;91:1194210. Published with permission of Oxford University Press.)

were smokers than among male smokers with lung cancer (17.4\%). The presence of K-ras mutation has been found to predict a poor prognosis. It has been found mainly in adenocarcinomas of the lung and only in patients with lung cancer who also have a history of smoking. ${ }^{30}$ This observation has led Nelson and colleagues ${ }^{30}$ to propose that "cigarette smoking induces K-ras mutations and the resultant clones are further expanded by a second event that may involve the growth-promoting effects of hormones (like estrogen) that may be specific for the adenocarcinoma histology."

Another area of investigation involves genetic differences in the gastrin-releasing peptide receptor $(G R P R)$ gene that is located on the $\mathrm{X}$ chromosome. The peptide plays a role in carcinogenesis by stimulating cell proliferation. ${ }^{31}$ Shriver and colleagues ${ }^{32}$ found that GRPR messenger RNA was detected more frequently in female than male nonsmokers (55\% vs $0 \%)$ and that among smokers GRPR messenger RNA was detected at lower levels of tobacco exposure in women than in men (75\% vs $20 \%)$. The authors concluded that the presence of two copies of the GRPR gene in women might play a role in their increased susceptibility to lung cancer. They also considered that GRPR expression in the airway, either de novo or as a result of exposure to tobacco, might predispose an individual toward the development of lung cancer. ${ }^{32}$

In summary, complex interactions of tobacco, tobacco smoke carcinogens, and biologic, hormonal, and genetic factors probably explain the differences in lung cancer risk between women and men. The precise nature of these interactions is the focus of ongoing investigations.

\section{Histologic Differences in Lung Cancer Between Men and Women}

In recent years, the histologic distribution of lung cancer has changed in both sexes. Four separate studies that used data from large cancer registries have demonstrated an overall decrease in the incidence of squamous cell carcinoma and an increase in the incidence of adenocarcinoma. ${ }^{33-36}$ The histologic distribution of lung cancer among women is distinctly different from that among men. Most nonsmokers and never-smokers with lung cancer are female, and adenocarcinoma prevails in these groups.

Like men, most women who acquire lung cancer are current or former smokers. The incidence of squamous cell cancer is lower among women than among men, ranging from $10 \%$ to $35 \%$ among women versus $30 \%$ to $55 \%$ among men. ${ }^{37-40}$ Small cell carcinoma histologic type accounts for $17 \%$ to $34 \%$ of lung cancers among women, in contrast to $15 \%$ to $20 \%$ among men. The percentage of lung adenocarcinomas among women has been higher than that among men since the 1960 s and averages between $20 \%$ and $60 \%$ in reported series. ${ }^{8-10,34,37-45}$ The incidence of adenocarcinoma among women who are nonsmokers is even higher. ${ }^{38,46}$ The bronchoalveolar subtype of adenocarcinoma is 2 to 4 times more common among women with lung cancer, particularly women who are nonsmokers, than among men and constitutes $3.6 \%$ of the cases in most series. ${ }^{8,37,47,48}$

The increased incidence of adenocarcinoma, as opposed to other histologic types of lung cancer, among women has been attributed to several causes, including biologic factors, such as hormones, enzyme phenotypes, and underlying lung disease, and environmental factors, such as second-hand smoke, to which women are more often exposed. ${ }^{34,46,49-52}$ For example, Adami and colleagues ${ }^{50}$ demonstrated a $30 \%$ increase in lung cancer among women receiving estrogen replacement therapy. The predominance of adenocarcinoma is particularly striking among nonsmokers, among whom the incidence ranges from $50 \%$ to $93 \% .^{38,43,46,51}$ Among nonsmokers with lung cancer, women outnumber men nearly 3:1 a fact that strongly supports a sex-based difference in the susceptibility toward the development of lung cancer, particularly adenocarcinoma of the lung.

\section{Sex-Based Differences in Prognosis and Outcome}

A retrospective study by Ferguson and associates ${ }^{53}$ of 478 men and 294 women with lung cancer demonstrated that the vast majority of patients are seen with advanced disease. Compared with men, however, a higher percentage of women were first seen with stage I disease (16.3\% vs $9.4 \%)$, whereas fewer had stage III disease (35.4\% vs $44.4 \%)$. Equal percentages of men and women were first seen with 
stage II (4.4\% vs $5.2 \%)$ and stage IV (43.9\% vs $41 \%)$ disease. A larger database analysis has suggested that stage I disease may be more equally distributed between men and women, but the fact remains that the majority of both men and women still are first seen with stage III or stage IV disease. ${ }^{37}$

Several studies, including an analysis of 1521 patients treated for small cell lung cancer in several Cancer and Leukemia Group B trials, have demonstrated that stage for stage, women exhibit better survival than do men. ${ }^{54-57}$ These studies also found that women tended to be seen with later stage disease, regardless of age, performance status, and whether they were enrolled in clinical trials. ${ }^{55}$ In the Southwest Oncology Group Study 8269 of limited stage small cell lung cancer, female sex was found to be a strong favorable independent predictor of survival in the univariate analysis. Five-year survival rates for women were 37\%, compared with $19 \%$ for men. However, female sex was not found to be a significant predictor of survival in the multivariate analysis. ${ }^{58}$

Several studies have shown improved survival for women treated for lung cancer. ${ }^{38,59-62}$ The 5-year survival is $15.6 \%$ for women, compared with $12.4 \%$ for men. ${ }^{61}$ It is of interest that a recent study by Minami and colleagues ${ }^{38}$ demonstrated that complete surgical resection was possible in women less often than in men because of increased incidence of malignant pleural effusion and $\mathrm{T} 4$ disease (19.9\% vs $14.4 \%)$. In cases of surgically resectable disease, however, survival after complete resection, especially for women older than 60 years, was markedly improved relative to their male counterparts. Much of the increase in survival is likely attributable to an increased life expectancy of women relative to men in this age group. When complete resection, greater life expectancy, and better performance status were all taken into consideration, women were found to have a 2-fold increased chance of long-term survival. ${ }^{63}$ In advanced non-small cell lung cancer a significant benefit was also seen, whereby the 2-year survival rate was more than doubled from $11 \%$ in men to $27 \%$ in women. ${ }^{64} \mathrm{Im}$ proved survival for women in every stage was shown in a retrospective cohort study of 104 men and women. ${ }^{65}$ Women lived an average of 12 months longer than men, even though equal numbers of stage I disease were present in both groups and more stage IV disease was present among the women. Overall, nearly all clinical studies performed that have focused on survival in women with lung cancer have found the female sex to be at least a positive or neutral prognostic factor. The dichotomy of lung cancer in women, as predominantly stage I or disseminated stage IV disease, has resulted in the appearance of equal survivals of men and women overall when in fact survival is improved among women when adjusted for the clinical stage of disease. This improved survival according to clinical stage was demonstrated in a small cohort study by Ouellette and associates $^{65}$ as well as a large population-based study from Poland $^{37}$ that analyzed more than 20,000 cases of lung cancer, of which nearly 3000 cases were in women. In this study, ${ }^{37}$ female sex was a positive prognostic variable in both univariate and multivariate analyses, behind clinical stage and performance status in terms of importance and clinical impact. That the survival benefit of female sex remains even when these other prognostic factors are taken into account suggests that the evaluation of disease-free survival and hormonal status will be important parameters to include in future sex-based clinical studies.

\section{Conclusion}

Evidence is accumulating to support the notion that the risk of development of lung cancer is different among women than among men. Women may be more susceptible to the ill effects of carcinogens in tobacco and tobacco smoke as a result of hormonal, genetic, and metabolic differences between the sexes. The preponderance of adenocarcinoma among women compared with men, and among women who are nonsmokers as well as younger women, argues in favor of a hormonal influence in this subtype of lung cancer. Future research efforts will continue to investigate and corroborate the findings outlined in this editorial and it is hoped will lead to a better understanding of lung cancer in both women and men.

\section{References}

1. Jemal A, Tiwari RC, Murray T, Ghafoor A, Samuels A, Ward E, et al. Cancer statistics, 2004. CA Cancer J Clin. 2004;54:8-29.

2. Ernster V. The epidemiology of lung cancer in women. Ann Epidemiol. 1994;82:1203-05.

3. Davis RM. Women and smoking in the United States: how lung cancer became an "equal opportunity" disease. Presented at the 7th World Conference on Tobacco and Health, Perth, Australia, April, 1990.

4. Fiore MC, Novotny TE, Pierce JP, Hatziandreu EJ, Patel KM, Davis RM. Trends in cigarette smoking in the United States: the changing influence of gender and race. JAMA. 1989;261:49-55

5. Centers for Disease Control and Prevention. Trends in cigarette smoking among high school students-United States, 1991-2001. MMWR Morb Mortal Wkly Rep. 2002;51:409-12.

6. Brownson RC, Chang JC, Davis JR. Gender and histologic variations in smoking-related risk of lung cancer. Epidemiology. 1992;3:61-4.

7. Kabat GC. Aspects of the epidemiology of lung cancer in smokers and nonsmokers in the United States. Lung Cancer. 1996;15:1-20.

8. Zang EA, Wynder EL. Differences in lung cancer risk between men and women: examination of the evidence. J Natl Cancer Inst. 1996; 88:183-92.

9. Risch HA, Howe GR, Jain M, Burch JD, Holowaty EJ, Miller AB. Are female smokers at higher risk for lung cancer than male smokers? A case-control analysis by histologic type. Am J Epidemiol. 1993;138: 281-93.

10. Harris RE, Zang EA, Anderson JI, Wynder EL. Race and sex differences in lung cancer risk associated with cigarette smoking. Int $J$ Epidemiol. 1993;22:592-9.

11. Osann KE, Anton-Culver H, Kurosaki T, Taylor T. Sex differences in lung cancer risk associated with cigarette smoking. Int J Cancer. 1993;54:44-8.

12. Prescott E, Osler M, Hein HO, Borch-Johnsen K, Lange P, Schnohr P, et al. Gender and smoking-related risk of lung cancer. The Copenha- 
gen Center for Prospective Population Studies. Epidemiology. 1998;9:79-83.

13. Kreuzer M, Boffetta P, Whitley E, Ahrens W, Gaborieau V, Heinrich $\mathrm{J}$, et al. Gender differences in lung cancer risk by smoking: a multicenter case-control study in Germany and Italy. Br J Cancer. 2000; 82:227-33.

14. Beckett AH, Gorrod JW, Jenner P. The effect of smoking on nicotine metabolism in vivo in man. J Pharm Pharmacol. 1971;23(Suppl):62S$70 \mathrm{~S}$.

15. Hecht SS, Hoffmann D. The relevance of tobacco-specific nitrosamines in human cancer. Cancer Surv. 1989;8:273-94.

16. Nakachi K, Imai K, Hayashi S, Kawajiri K. Polymorphisms of the CYP1A1 and glutathione S-transferase genes associated with susceptibility to lung cancer in relation to cigarette dose in Japanese population. Cancer Res. 1993;53:2994-9.

17. Hecht SS. Tobacco smoke carcinogens and lung cancer. J Natl Cancer Inst. 1999;91:1194-210.

18. Heminki K. DNA adducts, mutations and cancer. Carcinogenesis. 1993;14:2007-12.

19. Rom WN, Hay JG, Lee TC, Jiang Y, Tchou-Wong KM. Molecular and genetic aspects of lung cancer. Am J Respir Crit Care Med. 2000;161: 1355-67.

20. Ryberg D, Hewer A, Phillips DH, Haugen A. Different susceptibility to smoking induced DNA damage among males and female lung cancer patients. Cancer Res. 1994;54:5801-3.

21. Swenberg JA, Richardson FC, Boucheron JA, Dyroff MC. Relationships between DNA adduct formation and carcinogenesis. Environ Health Perspect. 1985;62:5-18.

22. Wei Q, Cheng L, Amos CI, Wang LE, Guo Z, Hong WK, et al. Repair of tobacco carcinogen-induced DNA adducts and lung cancer risk: a molecular epidemiologic study. J Natl Cancer Inst. 2000;92:1764-72.

23. Mollerup S, Ryberg D, Hewer A, Phillips DH, Haugen A. Sex differences in lung CYP1A1 expression and DNA adduct levels among lung cancer patients. Cancer Res. 1999;59:3317-20.

24. Stabile LP, Davis AL, Gubish CT, Hopkins TM, Luketich JD, Christie $\mathrm{N}$, et al. Human non-small cell lung tumors and cells derived from normal lung express both estrogen receptor alpha and beta and show biological responses to estrogen. Cancer Res. 2002;62:2141-50.

25. Caracta CF, Powell C, Brody JS. Estrogen receptor status of lung cancer cell lines [abstract]. Am J Respir Crit Care Med. 1999;159: A204.

26. Taioli E, Wynder EL. Endocrine factors and adenocarcinoma of the lung in women [letter]. J Natl Cancer Inst. 1994;86:869-70.

27. Kure EH, Ryberg D, Hewer A, Phillips DH, Skaug V, Baera R, et al. p53 mutations in lung tumours: relationship to gender and lung DNA adduct levels. Carcinogenesis. 1996;17:2201-5.

28. Toyooka S, Shimizu N, Gazdar AF, et al. Influence of gender on tobacco exposure related to p53 gene mutations in lung cancer: Analysis of the International Agency for research on cancer (IACR) database [abstract]. In: Abstracts of the 10th world conference on lung cancer. 2003. p. 26.

29. Guinee DG, Travis WD, Trivers GE, De Benedetti VM, Cawley H, Welsh JA, et al. Gender comparisons in human lung cancer: analysis of p53 mutations, anti-p53 serum antibodies and C-erbB-2 expression. Carcinogenesis. 1995;16:993-1002.

30. Nelson HH, Christiani DC, Mark EJ, Wiencke JK, Wain JC, Kelsey KT. Implications and prognostic value of K-ras mutation for earlystage lung cancer in women. J Natl Cancer Inst. 1999;91:2032-7.

31. Siegfried JM, DeMichele MA, Hunt JD, Davis AG, Vohra KP, Pilewski JM. Expression of mRNA for gastrin-releasing peptide receptor by human bronchial epithelial cells: association with prolonged tobacco exposure and responsiveness to bombesin-like peptides. Am J Respir Crit Care Med. 1997;156:358-66.

32. Shriver SP, Bourdeau HA, Gubish CT, Tirpak DL, Davis AL, Luketich JD, et al. Sex-specific expression of gastrin-releasing peptide receptor: relationship to smoking history and risk of lung cancer. J Natl Cancer Inst. 2000;92:24-33.

33. Wingo PA, Ries LA, Giovino GA, Miller DS, Rosenberg HM, Shopland DR, et al. Annual report to the nation on the status of cancer, 1973-1996, with a special section on lung cancer and tobacco smoking. J Natl Cancer Inst. 1999;8:675-90.
34. Travis WD, Lubin J, Ries L, Devesa S. United States lung carcinoma incidence trends: declining for most histologic types among males, increasing among females. Cancer. 1996;77:2464-70.

35. Levi F, Franceschi S, La Vecchia C, Randimbison L, Te VC. Lung carcinoma trends by histologic type in Vaud and Neuchatel, Switzerland, 1974-1994. Cancer. 1997;79:906-14.

36. Fry WA, Menck HR, Winchester DP. The National Cancer Database Report on Lung Cancer. Cancer. 1996;77:1947-55.

37. Radzikowska E, Glaz P, Roszkowski K. Lung cancer in women: age, smoking, histology, performance status, stage, initial treatment and survival. Population-based study of 20,561 cases. Ann Oncol. 2002; 13:1087-93.

38. Minami H, Yoshimura M, Miyamoto Y, Matsuoka H, Tsubota N. Lung cancer in women: sex-associated differences in survival of patients undergoing resection for lung cancer. Chest. 2000;118:1603-9.

39. Wynder EL, Muscat JE. The changing epidemiology of smoking and lung cancer histology. Environ Health Perspect. 1995;103 Suppl 8:143-8.

40. Wynder EL, Mabuchi K, Beattie EJ Jr. The epidemiology of lung cancer. Recent trends. JAMA. 1970;213:2221-8.

41. Wynder EL, Hoffmann D. Smoking and lung cancer: scientific challenges and opportunities. Cancer Res. 1994;54:5284-95.

42. Miller BA, Ries LA, Hankey BF, Kosary CL, Harras A, Devesa SS, et al, editors. SEER Cancer statistics review: 1973-1990. DHHS Publ No. (NIH) 93-2789. Bethesda (MD): National Cancer Institute; 1993. p. I.1-I.63.

43. Koo LC, Ho JH. Worldwide epidemiological patterns of lung cancer in nonsmokers. Int J Epidemiol. 1990;19 Suppl 1:S14-23.

44. Kabat GC, Wynder EL. Lung cancer in nonsmokers. Cancer. 1984; 53:1214-21.

45. de Perrot M, Licker M, Bouchardy C, Usel M, Robert J, Spiliopoulos A, et al. Sex differences in presentation, management and prognosis of patients with non-small cell lung carcinoma. J Thorac Cardiovasc Surg. 2000;119:21-6.

46. Fontham ET, Correa P, Reynolds P, Wu-Williams A, Buffler PA, Greenberg RS, et al. Environmental tobacco smoke and lung cancer in nonsmoking women. A multicenter study. JAMA. 1994;271:1752-9.

47. Kmietowicz Z. Women at double risk of small cell lung cancer. BMJ. 1998;317:1614.

48. Barsky SH, Cameron R, Osann KE, Tomita D, Holmes EC. Rising incidence of bronchioloalveolar lung carcinoma and its unique clinicopathologic features. Cancer. 1994;73:1163-70.

49. Cagle PT, Mody DR, Schwartz MR. Estrogen and progesterone receptors in bronchogenic carcinoma. Cancer Res. 1990;50:6632-5.

50. Adami HO, Persson I, Hoover R, Schairer C, Bergkvist L. Risk of cancer in women receiving hormone replacement therapy. Int J Cancer. 1989;44:833-9.

51. Gao YT, Blot WJ, Zheng W, Ershow AG, Hsu CW, Levin LI, et al. Lung cancer among Chinese women. Int J Cancer. 1987;40:604-9.

52. Chaudhuri PK, Thomas PA, Walker MJ, Briele HA, Das Gupta TK, Beattie CW. Steroid receptors in human lung cancer cytosols. Cancer Lett. 1982;16:327-32.

53. Ferguson MK, Skosey C, Hoffman PC, Golomb HM. Sex-associated differences in presentation and survival in patients with lung cancer. J Clin Oncol. 1990;8:1402-7.

54. Ramalingam S, Pawlish K, Gadgeel S, Demers R, Kalemkerian GP. Lung cancer in young patients: analysis of a surveillance, epidemiology, and end results database. J Clin Oncol. 1998;16:651-7.

55. Johnson BE, Steinberg SM, Phelps R, Edison M, Veach SR, Ihde DC. Female patients with small cell lung cancer live longer than male patients. Am J Med. 1988;85:194-6.

56. Spiegelman D, Maurer LH, Ware JH, Perry MC, Chahinian AP, Comis $\mathrm{R}$, et al. Prognostic factors in small-cell carcinoma of the lung: an analysis of 1,521 patients. J Clin Oncol. 1989;7:344-54.

57. Skarin AT. Analysis of long-term survivors with small-cell lung cancer. Chest. 1993;103(4 Suppl):440s-4s.

58. Albain KS, Crowley JJ, LeBlanc M, Livingston RB. Determinants of improved outcome in small-cell lung cancer: an analysis of the 2,580patient Southwest Oncology Group data base. J Clin Oncol. 1990;8: 1563-74. 
59. Mitsudomi T, Tateishi M, Oka T, Yano T, Ishida T, Sugimachi K. Longer survival after resection of non-small cell lung cancer in Japanese women. Ann Thorac Surg. 1989;48:639-42.

60. Graham MV, Purdy JA, Emami B, Matthews JW, Harms WB. Preliminary results of a prospective trial using three dimensional radiotherapy for lung cancer. Int J Radiat Oncol Biol Phys. 1995;33:9931000.

61. Ries LA, Kosary C, Hankey BF, et al, editors. SEER Cancer statistics review: 1973-1993. DHHS Publ No. (NIH) 96-2789. Bethesda (MD): National Cancer Institute; 1996.

62. Albain KS, Rusch VW, Crowley JJ, Rice TW, Turrisi AT, Weick JK, et al. Concurrent cisplatin/etoposide plus chest radiotherapy followed by surgery for stages IIIA (N2) and IIIB non-small-cell lung cancer: mature results of Southwest Oncology Group phase II study 8805 . J Clin Oncol. 1995;13:1880-92.

63. Bouchardy C, Fioretta G, De Perrot M, Obradovic M, Spiliopoulos A. Determinants of long term survival after surgery for cancer of the lung: a population-based study. Cancer. 1999;86:2229-37.

64. Paesmans M, Sculier JP, Libert P, Bureau G, Dabouis G, Thiriaux J, et al. Prognostic factors for survival in advanced non-small-cell lung cancer: univariate and multivariate analyses including recursive partitioning and amalgamation algorithms in 1,052 patients. The European Lung Cancer Working Party. J Clin Oncol. 1995;13:1221-30.

65. Ouellette D, Desbiens G, Emond C, Beauchamp G. Lung cancer in women compared with men: stage, treatment, and survival. Ann Thorac Surg. 1998;66:1140-3.

\section{The Journal of Thoracic and Cardiovascular Surgery Conflict of Interest Policy}

To assure fairness to authors submitting work for consideration in The Journal of Thoracic and Cardiovascular Surgery, a mechanism exists for managing conflicts of interest. The editor and each of the section editors complete a "Conflict of Interest" form that identifies any and all relationships with commercial and other academic entities. When the editor has a potential conflict because of a relationship with another entity or author, the editor appoints an alternate editor from among the section editors or editorial board members who assumes the entire responsibility for final decisions on the manuscript in question. The editor does not read the reviews that are submitted nor engage in discussing the manuscript prior to the final decision. When the conflict of interest involves a section editor, a "guest section editor" is appointed who fills the role normally played by the conflicted section editor. All members of the editorial board and reviewers are asked to indicate any conflict of interest when they agree to review a manuscript. 